\title{
THE COOPERATIVE EXPERIENCE OF COGON FARMERS: FOOD SECURITY FOR SMALL FARMERS
}

\author{
SHELDON IVES AGATON, SARAH CAJIPO, DAISY LAGDAMEN, SHERWIN \\ ESPAÑO, KAY BATHALA SANTOS \& ROSALITA DULA
}

\begin{abstract}
Cooperativism is a method introduced by people in a society to neutralize the competitive prices of goods from among business sectors. It is a way for people to come together, put up their goods and services as one, and with the end in view of benefiting from their products. The purpose of this study is to appraise the fundamental function of cooperativism and how it can assist and sustain small farmers in their aim for food security. This work utilized hermeneutical phenomenology in understanding the lived experiences of small farmers in Barangay Cogon, Tanauan, Leyte, Philippines from the establishment of their cooperative, its operation, and its eventual success in giving them food security in the process. The results indicate that farmers were hesitant in establishing a cooperative because of the groundwork that accompanies it. But with the aid of the faculty members of the Eastern Visayas State University, the farmers underwent education on the nature of cooperativism. From there, the faculty members allowed the farmers to cultivate discipline, sustenance, and business integrity while operating the cooperative. Constant monitoring from the faculty members over the farmers was necessary to ensure that the cooperative was consistently maintained thereby achieving stability and eventual food security. For years now, the cooperative has helped its members substantially. Coincidentally, the occurrence of the covid-19 virus has made significant changes or damages to human life and properties, but this cooperative gave hope and food sustenance to its members. This study hopes that the effort of the initiators coupled with the cooperation and effort of the cooperative members exemplify the need to proliferate cooperativism in every society especially among poor farmers.
\end{abstract}

Keywords: Cooperativism; Agricultural cooperative; Theory of cooperation; Phenomenological study; Research and extension service; Food security

\section{INTRODUCTION}

The Philippines is primarily an agricultural country. The entire archipelago is composed of vast agricultural land areas and caters a wide range of agricultural products like rice, corn, root crops, vegetables, and fruits. The country's Gross Domestic Product (GDP) for the second quarter of the year 2021 has posted an $11.8 \%$ growth. The area of agriculture, however, suffered a decline following a contraction of livestock products at $-0.1 \%$ (Philippine Statistics Authority 2021). Agricultural farming is not a new practice in the Philippine setting. In the 1980's and 1990's, the Philippine Agrarian Reform Council Secretariat has recorded numerous variations of these types ranging from small, medium to large farms (Araullo 2006). The comprehensive agrarian reform program of the Philippine government has tried to be an aspect of change and hope for these farmers as they continued to distribute agricultural lands to the needy farmers. However, these farmers do not only need lands but also tools and implements to actualize their objective of producing farm products. Planting rice is generally done by the hands, but its land 
preparation, harvesting, and drying are better realized with the use of machines (Agaton 2021). It becomes a major setback for a farmer's production initiative sans these types of machinery. He may be able to rent them, but the expenses shall be incurred against him.

The first cooperatives in history were an alternative way of coping with the capitalistic situation of societies. The expensive commodities they were experiencing paved the way for cooperatives to combat the difficult situation (Şahin \& Hacisalihoğlu 2018). The Philippines' national hero, Dr. Jose P. Rizal, while an exile in Dapitan, established a cooperative to compete with the high-priced commodities of the Chinese merchants (Zaide 2003). The residents of Dapitan gradually eluded the capitalistic mindset of these merchants by patronizing their products and benefitting from their proceeds.

Republic Act No. 6938 or the Cooperative Code of the Philippines provides a policy of the State to foster the creation and growth of cooperatives as a practical vehicle for promoting self-reliance and harnessing people power towards the attainment of economic development and social justice (Nolledo 1996). The creation of cooperatives in the country shall be an avenue for the people particularly the underprivileged to achieve a group that can sustain an economic objective (Castillo 2003). Under the concept of cooperativism, the members are likewise the owners of the establishment. A cooperative is people-centered since its formation can be realized through the initiative of the people themselves sharing a common goal, and that this commonality will come into fruition through their hard work and dedication (Şahin \& Hacisalihoğlu 2018). In that sense, since they are owners of it, they will work an extra mile to sustain or improve it.

In the year 2017, the social sciences and economics department of the Eastern Visayas State University Tacloban City, Philippines initiated an extension activity at Barangay Cogon, Tanauan, province of Leyte. They chose this area since it was closer to the university, and the faculty members felt that the farmers and the establishment of a cooperative will be constantly monitored of their daily operations and that any misdemeanor detrimental to the cooperative can be outright rejected. These teachers had the end in mind of stabilizing food security among small farmers in this area through cooperativism. One of the goals of an extension activity of a state university is to educate and impart some knowledge or skill to a farmworker and his family with the end in view of elevating his socio-economic way of life (Nierras 2016). A farmer is a necessary component in a society like the Philippines being an agricultural country. He needs empowerment as his job is necessary to the country being an agricultural one. In the event of successful education among these small farmers across the country, agricultural food production will increase giving food security to many parts of the archipelago. Agricultural products become rampant because of the dedication of these people. They need to be empowered and supported for them to work better for the benefit of the country's economic growth and stability. The production of farm products through these farmers can help achieve food security in a society (Agaton 2021). The faculty members of this university pursued this project to help this type of worker. Just like any undertaking, the task was difficult because the recipients were initially reluctant about the idea. But through the persuasion and massive education upon the farmers, the latter finally understood the help that a cooperative can give to them if only they were to open the idea.

It did not however culminate there. The teachers further persisted in assisting the recipients in organizing the cooperative from the creation of its by-laws, then to the election of their officers up to the recruitment of its members. They were further taught about financial management so that the cooperative will prolong. Since then, the cooperative has operated and up to the present day, new members have joined and enjoyed the benefits of their cooperative. From time to time, the teachers regularly visit the place to check its functionality.

In this paper, using the hermeneutical phenomenology method, the lived experiences of several members of the Cogon Small Farmers Cooperative were deduced through interviews 
and tried to find out the benefits they experienced through it. The increase of both membership and capital build-up demonstrates the utility of it towards them.

This study was aimed at knowing and understanding the lived experiences of certain members of the Cogon Farmers Cooperative. The method used allowed the farmers to actively engage with the researchers to profess the features that encouraged them to join and establish the Cogon Farmers' Cooperative and the benefits that they have received from it even during this time of pandemic.

\section{Framework of the Study}

This research and extension work is founded on the economic theory of cooperation introduced firstly by Ivan V. Emelianoff in 1947 and succeeded by the Theory of Cooperation of Deutsch and Krauss in 1962. Several scholarly articles that have stressed the nature, importance, and benefits of a cooperative theory and cooperativism have also made a significant contribution to the completion of this work (Altman 2009; Emelianoff 1995; Fang 2016; Jacques, Verginio \& Estevam 2019; Royer 2014; Tjosvold 1984; Şahin \& Hacısalihoğlu 2018). The economic theory of cooperation postulates that a cooperative is an aggregate of economic units which finds fulfillment through its members who must be active and controlling participants of it (Emelianoff 1995). The cooperation theory can aid an organizational structure in its social dynamics like the interaction and production of its members. A goal of an organization needs the collaboration of its members to achieve the projected standard (Tjosvold 1984). In the neoclassical approach to cooperation, the behavior of a certain cooperative can be evaluated whether its operation conforms with the macro-level of marketing where it is a part of (Royer 2014). For instance, farm supplies and the implements that farmers utilize can be provided by the cooperative where they are members. The cooperation theory provides the roles that managers, directors, and members must assume. Their respective roles are important in the continuation of their organization (Tjosvold 1984).

Numerous cooperatives have been operational in the country and their constitution and by-laws must conform with the legal standard (Nolledo 1996). This is to ensure that legal requirements and processes are strictly followed and that future illegal acts may be avoided. In the Luzon area, the government reported that in the year 2003, the top four performing agricultural cooperatives have been recording and these groups have catered to the needs of their member-farmers (Castillo 2003). The Philippines, as an agricultural country needs to encourage its people to adhere more to cooperativism. Massive education must be made to propagate the advantages of creating or joining a cooperative. It may not be an absolute solution against poverty, but it helps poor farmers from thriving the demands of farming and their family needs (Cudis 2019).

The faculty members of the Social Sciences Department of Eastern Visayas State University spearheaded an extension activity to farmers in Cogon, Tanauan, Leyte, Philippines as part of their core function. As a state university, teachers are mandated by law to conduct extension activities like adopting a barangay and help the inhabitants of that place learn a livelihood project. This is an example of a supply and purchasing cooperative wherein members have access to its goods and services. Here farmers can avail their farming needs through a loan at a reasonable price or monthly amortization (Altman 2009), notwithstanding the enjoyment they may experience from the same coop by way of dividends and patronage refund. The farmers in this locality were given series of lectures as to the idea of cooperativism. In Biliran, Philippines, faculty members of Biliran Island Province State University conducted an extension activity with the primary objective of gathering and providing for their farming needs (Nierras 2016). This is one of the better avenues for a state university to extend its knowledge to those who need it like the farmers. 
A cooperative is owned by its members. As owners, they need employees to run the operation of their office. These employees must be remunerated justly so legal violations will be avoided under the labor law. Paying them according to the minimum wage standard set forth by labor law will allow them to support the needs of their respective families (Jacques, Verginio \& Estevam 2019). Some cooperatives have ceased their operation because of legal issues that they committed.

The Cogon Small Farmers Cooperative has brought improvement into the lives of its members and even non-members. The teachers of the social sciences department replicated the existing and flourishing cooperatives found in other parts of the country. They studied the significant contribution of it towards farmers, especially the poorer ones. Learning from those coops propelled them into establishing one in the nearby town. The establishment of these agricultural cooperatives has brought tremendous benefits for their farming needs and their families' needs as well (Manto-Beltran 2017).

\section{METHODOLOGY}

\section{Research Design}

This research and extension paper utilizes the hermeneutical phenomenological method for its completion by using interviewees, participant observation, and group meetings. Participants were asked questions about their lived experiences in the cooperative that they are a part of. Questions revolved around the necessity of the cooperative, the difficulties if there were, and the achievements that they have obtained as members or even non-members of it.

The interview process was utilized because it is the primary way of producing a phenomenological research work. Further, the study utilized the gathering of documents like constitution and by-laws, correspondence concerning the nature of their group as a cooperative, photographs, and other material that have relevance or connection to the subject being researched.

\section{Location of the Study}

Barangay Cogon, Tanauan, Leyte, Philippines was the research locale of this work. It is situated 12 kilometers south of Tacloban City, the Capital of Region VIII. The locale is accessible by any means of land transportation since the road to it is concrete.

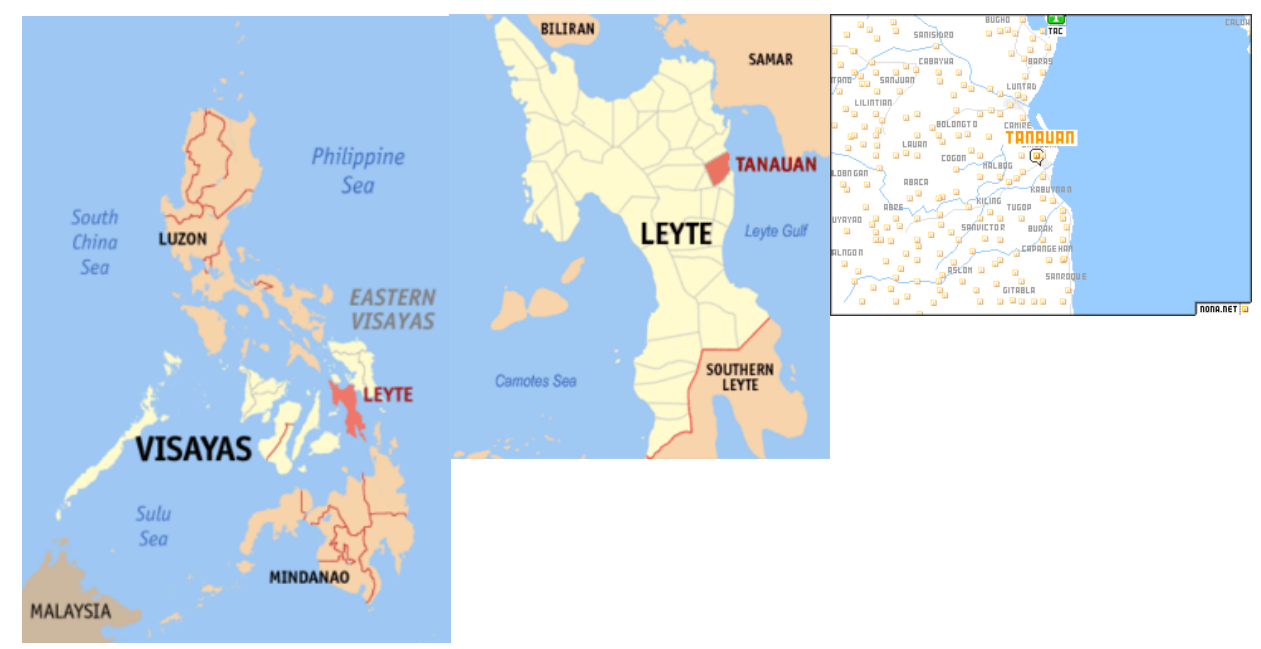




\section{Research Respondents}

The interviewees in this study were the beneficiaries of the Cogon Small Farmers Cooperative. They include the founding members, the officers, the old members, the new members, and even non-members. They were randomly selected. To facilitate focus group discussion, two groups were created. The first group (FG1) were members of the cooperative who were either old or new members. Founding members and officers were likewise included in this group. The second group (FG2) were non-members of the cooperative but are allowed to avail themselves of the services of the cooperative. The information drawn from them was the primary data in the fruition of this research work. Their cooperation and dedication from the outset of the cooperative's creation up to its operation and subsequent success are truly attributable to them.

\begin{tabular}{|c|c|c|c|}
\hline \multicolumn{4}{|c|}{ (FG1) LIST OF OFFICERS AND MEMBERS } \\
\hline Name & Position & Address & Work \\
\hline Ariel Lerios & President, BOD & $\begin{array}{l}\text { Barangay Cogon, } \\
\text { Tanauan, Leyte }\end{array}$ & Farmer \\
\hline Nelson Meniano & Vice-President, BOD & $\begin{array}{l}\text { Barangay Cogon, } \\
\text { Tanauan, Leyte }\end{array}$ & Farmer \\
\hline Edna Rabina & Secretary, BOD & $\begin{array}{c}\text { Barangay Cogon, } \\
\text { Tanauan, Leyte }\end{array}$ & Farmer \\
\hline Gerry Cauntio & Treasurer, BOD & $\begin{array}{c}\text { Barangay Cogon, } \\
\text { Tanauan, Leyte }\end{array}$ & Farmer \\
\hline Ricardo Yamon & Auditor, BOD & $\begin{array}{l}\text { Barangay Cogon, } \\
\text { Tanauan, Leyte }\end{array}$ & Farmer \\
\hline Maximino Cadion & BOD & $\begin{array}{l}\text { Barangay Cogon, } \\
\text { Tanauan, Leyte }\end{array}$ & Farmer \\
\hline Manilyn Candela & BOD & $\begin{array}{l}\text { Barangay Cogon, } \\
\text { Tanauan, Leyte }\end{array}$ & Farmer \\
\hline Romeo Miniano & Member & $\begin{array}{l}\text { Barangay Cogon, } \\
\text { Tanauan, Leyte }\end{array}$ & Farmer \\
\hline Leo Candela & Member & $\begin{array}{c}\text { Barangay Cogon, } \\
\text { Tanauan, Leyte }\end{array}$ & Farmer \\
\hline Alejandro Caintic & Member & $\begin{array}{c}\text { Barangay Cogon, } \\
\text { Tanauan, Leyte }\end{array}$ & Farmer \\
\hline Fortunato Rabina & Member & $\begin{array}{c}\text { Barangay Cogon, } \\
\text { Tanauan, Leyte }\end{array}$ & Farmer \\
\hline Eric Yamon & Member & $\begin{array}{l}\text { Barangay Cogon, } \\
\text { Tanauan, Leyte }\end{array}$ & Farmer \\
\hline Jurnel Peñalber & Member & $\begin{array}{l}\text { Barangay Cogon, } \\
\text { Tanauan, Leyte }\end{array}$ & Farmer \\
\hline Lolita Miniano & Member & $\begin{array}{l}\text { Barangay Cogon, } \\
\text { Tanauan, Leyte }\end{array}$ & Farmer \\
\hline Jocelyn Molon & Member & $\begin{array}{c}\text { Barangay Cogon, } \\
\text { Tanauan, Leyte }\end{array}$ & Farmer \\
\hline April Grace Lirios & Member & $\begin{array}{l}\text { Barangay Cogon, } \\
\text { Tanauan, Leyte }\end{array}$ & Farmer \\
\hline Mary Jane Cauntic & Member & $\begin{array}{l}\text { Barangay Cogon, } \\
\text { Tanauan, Leyte }\end{array}$ & Farmer \\
\hline Jessica Picoy & Member & $\begin{array}{l}\text { Barangay Cogon, } \\
\text { Tanauan, Leyte }\end{array}$ & Farmer \\
\hline Virginia Amor & Member & $\begin{array}{c}\text { Barangay Cogon, } \\
\text { Tanauan, Leyte }\end{array}$ & Farmer \\
\hline
\end{tabular}




\begin{tabular}{|c|c|c|c|}
\hline \multicolumn{4}{|c|}{$\begin{array}{l}\text { (FG2) LIST OF SELECT NON-MEMBERS } \\
\end{array}$} \\
\hline Herminia Cesar & Non-Member/Borrower & $\begin{array}{c}\text { Barangay Cogon, } \\
\text { Tanauan, Leyte }\end{array}$ & Farmer \\
\hline Victoria Yepes & Non-Member/Borrower & $\begin{array}{c}\text { Barangay Cogon, } \\
\text { Tanauan, Leyte }\end{array}$ & Farmer \\
\hline Judita Lerios & Non-Member/Borrower & $\begin{array}{c}\text { Barangay Cogon, } \\
\text { Tanauan, Leyte }\end{array}$ & Farmer \\
\hline
\end{tabular}

\section{Research Instrument}

This study is anchored on the research instrument containing three major themes. The primary and the very essence of this study begins with the desire and encouragement that these farmers experience on the nature and operation of a cooperative. To initiate a cooperative is not easy because of vital things like paperwork and capital to operate. It will be illegal to engage in this kind of project without the necessary government requirements. Neither will the cooperative function without initial capital. The second concern tackled the benefits for both members and non-members gained from the cooperative. As the cooperative functions legitimately and efficiently, its members will also begin to get subsidies from it which is a promising sign. A cooperative will continuously grow it is managed effectively and efficiently. The products and the profit it produces will stabilize its economic status, thereby ensuring its members of food security. Thirdly, the interview considered the status of the cooperative as well as its proficiency with the world suffering from the pandemic. Many businesses have closed and many people have lost their jobs. The members must be asked whether their cooperative was able to live through the hardships brought about by the Covid-19 phenomenon.

\section{Source of Data}

This study secured the necessary permit from the local government of Tanauan, Leyte before proceeding to the locale. The letter seeking permission informed the said local government unit that the objective of the study was to inquire into the continuous development of the Cooperative the farmers at barangay Cogon, Tanauan, Leyte helped to establish.

Separate letters were also sent to the cooperative members/interviewees informing them of the nature of the research work and that they were part of the data gathering procedure. It was also an avenue for them to prepare beforehand any knowledge or document that they can share and help facilitate the interview.

During the data gathering process, a cassette tape recorder was used to gather primary sources of information. A video camera was also used because it was more effective in transferring and eventually disclosing information to the readers of this research work (Foronda 1993).

All the information obtained from the data gathering was transcribed and written on paper to produce a hard copy of the account. Thereafter, if there was a need to translate the information into the English language, it was done to arrive at an account that was probably intelligible to those who cannot speak and understand the vernacular or native tongue of the place. It is noted here that sometimes the researcher was having a hard time interviewing some of the informants because some of them had a hearing defect. Fortunately, because of persistence, vital information was still deduced.

Further, the accounts were integrated according to the relationship of which from one to the other. This entailed easier access to the ideas obtained from the data gathering and facilitated their infusing to the whole research work. 


\section{RESULTS AND DISCUSSION}

The emergence of various types of cooperatives in the country has assisted the marginalized sector of the Philippines like the poor. This is part of the primary thrust of the Cooperative Development Authority. Numerous cooperatives in the country have succeeded, but there are some which failed. Either reason did not deter Filipinos from making this kind of association because they are fully aware of the important assistance that it caters to, especially on the financial aspect.

Farmers are generally poor and helping them bond together to create a cooperative will aid them with their basic farming needs and their families. It may not be an absolute solution to their needs, but it can somehow lessen the burden of farming and attending to family needs. The concept of cooperativism, the initiative of the teachers, the reality and importance of agricultural cooperatives, and the needs of the Cogon farmers in Tanauan, Leyte, Philippines have resulted in the conception of this research and extension work. The success of many agricultural cooperatives in both the islands of Luzon and Mindanao might be replicated in Leyte in order also to assist the needy farmers. The initial stages met with difficulty because reluctance was prevalent among the farmers, but persistence and educational persuasion led to their subsequent approval on the proposed endeavor.

\section{Cogon Small Farmers' Cooperative: Its Onset}

The extension activity commenced in 2017 with the end in mind of helping the farmers of that area hurdle the challenges of farming activities. Farming is not new to this locale because the activity has been going on for many years as it is an agricultural area. But the concept of Cooperative coupled with farming never come across their minds. The faculty members of the social sciences and economics department of the Eastern Visayas State University came up with the idea of helping them through cooperativism banking on the thought that a cooperative not only benefit the members (Şahin \& Hacisalihoğlu 2018) but the entire economy of the country (Araullo 2006). They form a vital part of the sustenance of the food supply in the country (Agaton 2021). They need to be empowered through the effort of the government that they are essential in the country's quest for prosperity (Manto-Beltran 2017).

It is unfortunate that every election in the Philippines, the farmers' sector in our society has been at the forefront of campaign strategies. The battle cry for some politicians resounds that as an agricultural country, the Philippines needs farmers in its economic endeavors. In the Philippines, some of these politicians are the rich elite who owns vast land areas in the country. The blatant reality of the landlord and tenant relationship in this instance is susceptible to abuse (Fang 2016). Some politicians through the help of Many poor farmers and tenants at that do not have the liberty to elect somebody of their own will. The creation of bogus non-government organizations dedicated to helping farmers was fortunately discovered in 2010 leading to the arrest of some personalities and the indictment of certain politicians (Inquirer Research 2019).

This reality continues to haunt farmers time and again as the promises of some politicians remain inutile right after election time. This is not however absolute because there are those leaders who truly have the heart and dedication towards helping the farming sector. This is the starting point of the faculty members of this university. It is the declared policy of the State to encourage the creation of cooperatives to help achieve sustainable development (Philippine Cooperative Code 2008).

Most of the farmers in that area were financially wanting. The financial aspect was of greatest importance since most if not all of them are poor. (Han waray pa coop, ginbabaligya ko nala it akon mga gamit para hit mga panginahanglan, R. Miniano, Personal Interview, November 8, 2020) One interviewee said that when money becomes difficult, he would just 
sell his farming equipment or implement to meet basic needs (FG1 2020). It tends to make his livelihood harder the next time he engages in. (Mayda ngani hadton una, ginbaligya ko nala an akon humay ha barato nga presyo kay makuri man, R. Miniano, Personal Interview, November 8,2020 ) Another interviewee was forced to sell his produce at a lesser price because he wanted to give his child some school needs (FG1 2020). These incidents can be repelled when a cooperative is functional in their area. A cooperative can supplant certain needs of its members especially in trying times at a very minimal interest rate. Besides, in a cooperative, members are owners of the same. They have a patronage refund every time they avail a loan window from it (Aralar 2007).

Groundwork happened with the faculty members doing a massive education on the farmers of that locale. From organization to financing and its management, the faculty members worked tirelessly to finish what they started. Creating a cooperative is not an easy task. There have been numerous cooperatives that resulted in bankruptcy due to certain elements like mismanagement, wrong investments, and faculty members. The organizers need to iron things up to avoid the same mistakes.

\section{The Legal Framework}

Everything must be legal. Hence, the faculty members secured the required documents from government offices like the Cooperative Development Authority (CDA), the Department of Labor and Employment (DOLE), and the Department of Science and Technology (DOST).

The CDA has the regulatory power over all cooperatives in the Philippines. All created cooperatives must register with it to be duly authorized and function as such. Meanwhile, a cooperative employs people to man its day-to-day operations. As employees, they must be protected by existing laws and the DOLE. Abuses committed by employers against employees happen every now and then where some disputes would even reach the Supreme Court for adjudication. It would be worse when employers are not registered with the DOLE and employees of them are susceptible to abuse. Throughout the world, abuses continue to happen against workers. Their rights can only be safeguarded when existing laws are imposed (Jacques, Verginio \& Estevam 2019).

The framework that guides the operation of their cooperative is their working constitution and by-laws. Through the assistance of the faculty members, these farmers were able to write their legal framework. This is a necessary paper for every association, corporation, or cooperative because all members are bound by it and their rights are duly secured by it. it will be the basis of the board of directors, officers, and members' functions. Besides, a cooperative cannot secure all the legal documents mentioned above without first framing its constitution and by-laws.

\section{Lived Experiences of Farmer-Members: Towards Attaining Food Security}

After a few years of operation, the Cogon Farmers' Cooperative survived various tests to prolong the services to its members. Per record, the cooperatives capital build-up is improving which is a manifestation that they have learned from the frequent education from the teachers who organized it. They are monitored regularly by the faculty members of EVSU to ensure that good practices are perpetuated. Despite expenses incurred like salaries to its employees, the cooperative maintains its financial integrity. Besides, its projects and programs, for as long as they serve the interest of the cooperative are generally tax-exempt (Araullo 2006). During the interviews, some members profoundly expressed positive effects of it. One member said that (maupay iton cooperative kay nakautang ka hin mga liso, M. Cadion, Personal Interview, 
November 6, 2020) this cooperative is good because he can owe seedlings from it at a very low price compared to others (FG1 2020).

(ha cooperative mayda nabalik ha imo nga kwarta sugad hit dibidindo didto hiton katapusan hiton tuig, M. Candela, Personal Interview, November 9, 2020) In a cooperative, a member normally gets patronage refund and dividend at the end of the year (FG1 2020). This is because cooperative members are also owners of it. In fact, one member said that (iton nakakaupay hiton cooperative kay ma miembro ka ma diri, mayda ka nakukuha nga benepisyo kahuman hiton tuig, J. Molon, H. Cesar, Personal Interview, November 13, 2020) the good thing about the organization is, whether you are a member or not, you get to receive benefits after the year (FG1 2020) (FG2 2020). (nakakaloan ka na, basta magbayad ka la hit binulan, mayda gihap nimo makakarawat dida hit imo ginbinayad katapos hit tuig, A. Lerios, Peronal Interview, November 6, 2020) One gets to receive a loan from it, pays its amortization but nevertheless receives a portion of his amortization at the end of the year (FG1 2020). (nalilipay ako kay yana nga Disyembre, mayda ko makakarawat nga 3,000, R. Miniano, Personal Interview, November 8, 2020) One interviewee was even happy to share that this coming December, the cooperative will have a share out of 3,000 pesos for every member (FG1 2020). (an mayda liwat mga utang pa, iibanan anay ugsa ihatag iton dibidindo, G. Cauncio, Personal Interview, November 6,2020$)$ Those with outstanding debts will still be given minus their remaining balance (FG1 2020).

The cooperative can lend a considerable amount to its members despite meager capital compared to other cooperatives, but it can sustain the financial needs of its members. The officers only need to be critical of their capital and scrutinize the financial capacity to pay of the borrowing member. (diri kami nagaalang panukot, ngan diri kami nagaalang pag blacklist hiton diri namamayad, A. Lerios, Personal Interview, November 6, 2020) Their cooperative does not hesitate to blacklist delinquent borrowers, and it is persistent in collecting the remaining balances from this type of borrowers (FG1 2020). (Dako gud nga bulig kay kaya magpautang iton coop hin 2,000 ngada ha 15,000 G. Cauntio, Personal Interview, November 6,2020 ) It is a big help because the association can lend a range of 2,000 to 15,000 pesos depending on the need of the borrower (FG1 2020). 15,000 pesos is already a decent amount if one wants to start owning a micro-business. (Ugsa iton nautang makadara, naagi anay iton hiya hin mahugot nga edukasyon ngan pahinumdum para magamit hin sakto iton iya inutang, N. Meniano, Personal Interview, November 13, 2020) Before a member avails a loan window, he undertakes a stringent financial education from the committee concerned. This process assists the borrower to spend the money according to the intended purpose (FG1 2020). (Masayon la pagbayad kay habubo man iton tubo, V. Amor, J. Lerios, Personal Interview, November 13, 2020) The general pronouncement from both members and non-members is that the interest of the loan is minimal, so it is easy to repay (FG1 2020) (FG2 2020).

(Diri la kwarta iton puydi ipautang hiton asosasyon L. Miniano, V. Yepes, Personal Interview, November 21, 2020) Money is not the only thing available from the association (FG1 2020) (FG2 2020). Farming tools, machines, and implements are also available for rent. It has a dryer for newly harvested grain. It also has a tractor and thresher. The payment of rent may be done through a loan. If contracted with another businessman, he needs to pay the fee in cash. (Damu la iton puydi matagamtaman hini nga asosasyon, L. Miniano, V. Yepes, Personal Interview, November 21, 2020) All these loan opportunities are affordable according to the information given during the interviews (FG1 2020) (FG2 2020). When one is a member, he is charged a 2 percent interest rate while a non-member is charged 5 percent. This schema encourages more farmers to become members which is a good sign for every cooperative. As a transformational leading-edge, Ravanera said the cooperative movement in the country is up to the task of advocating for the much-needed paradigm shift that will liberate the people from the quagmire of poverty (Cudis 2019). 
Both members and non-members of this cooperative have improved their purchasing power. The financial education that they undergo allows them to utilize the money reasonably. They are reminded that using the money arbitrarily could lead to financial loss and may result in being blacklisted in the cooperative thereby disabling them from further profiting from their association on the occasion that they no longer pay their monthly amortization. The cooperative also aided their anticipation for food security. If in the past, buying seedlings from stores was a problem, this major concern was addressed by the cooperative. They can just go to their office, apply for assistance, get the seeds, then begin cultivating their land. This was in a form of a loan at minimal interest. Planting and harvesting became a cycle throughout the year without interruption. The cooperative has helped them financially and guaranteed their food security.

Even in death, the bereaved family of the deceased member receives something from the cooperative. When sickness befalls a member, the association also caters assistance. (nakakbulig bisan ha kamatayon kay mayda suporta hiton coop, E. Yamon, Personal Interview, November 21, 2020) Either way, the pain or burden that a family encounters is lessened with the support of the cooperative (FG1 2020). Filipinos are fond of celebrating even in death because they want to celebrate the life and times of the dearly departed. In fact, the relatives of the deceased would arrive from various places to pay their last respect. It would be difficult to attend to the basic needs of these mourners as some of them are also poor, (bisan namanla ha talagudti, mayda gud nabubulig iton coop, E. Yamon, Personal Interview, November 21, 2020) but their cooperative can assist even in the smallest way possible (FG1 2020). (Ngan para ha akon, iton pinakamaupay iton relasyones nga amon nahuhurma kumo mga miembro, A. Lerios, Personal Interview, November 6, 2020) And the better thing if not the best thing about it is the relationship among members is strengthened (FG1 2020). An organization can achieve greater accomplishments if most or all of its members have one goal in mind and that they strive in unity to reach that goal.

\section{Covid-19 and the Cogon Small Farmers' Cooperative}

The covid-19 pandemic has been a menace to many areas of human activity ranging from life itself, jobs, businesses, and properties. Globally, millions have died due to the virus and many businesses have shut down (Maboloc 2020). Due to business losses, jobs among ordinary workers were affected diminishing the purchasing power of man.

Agricultural lands have a brighter side. As long as man equips himself with creativity and hard work by tilling the land and capitalizing on its advantages, there will be benefits that can be derived from it (Agaton 2021). The members of the cogon farmers continued to operate despite the pandemic. The farmers were aware of the economic depletion that every country was experiencing, but nevertheless pursued its daily operation coupled with persistent planting of crops. The year 2020 may have been the worst episode of the covid-19 crisis, but these farmers managed to cross the difficult path to recovery.

The cooperative helped sustain the basic needs of sowing, and it supported the daily needs of their respective families as well. The growth of the cooperative may have slowed down due to the pandemic, but the members managed to escape bankruptcy. They have shown resilience despite the challenging reality. 


\section{CONCLUSION}

The Cogon Small Farmers Cooperative has been beneficial both to members and non-members alike. The primary recipients of it are the members and the latter enjoys the perks of being such. Non-members also benefit from it because they are also allowed to borrow although at a higher interest rate. This strategy invites non-members to become members since it is not only the lower interest rate that they can avail of but also other services of the coop. However, there are still other avenues for improvement like accepting more members, buying more farming equipment, and increasing other loan windows. Quality members will not only increase the capital of the organization but will have the flexibility to opening new loan opportunities. Generally, the members are hopeful that the association will be perpetuated because it has given them better purchasing power and guaranteed their food security. They can now plant then harvest throughout the year through the aid of the cooperative.

The covid-19 pandemic has disturbed countless lives across the globe. Many lives were lost due to infection from the disease. Some businesses shut down causing massive job losses incapacitating the human person of his purchasing power. Back in 2017, the faculty members of the Eastern Visayas State University did not foresee that a pandemic will occur in 2020. Their intention was simply to initiate and educate the farmers of Cogon about the nature and the goodness of a cooperative. But the cooperative certainly serves the needs of both members and non-members residing in that locale at this time of tragedy. These two groups of people merely worked hard and cooperated resulting in a functional cooperative. On the one hand, the Cogon Small Farmers' Cooperative has sustained its existence and services towards both its members and non-members. On the other hand, farming continues in that area and farmers are striving hard to produce agricultural products primarily for their locality's consumption. The pandemic may have disturbed human lives and even this cooperative, but resilience and patience have hurdled the difficult situation and it remains operational until today. It has been helpful with or without any catastrophe.

The Cogon Small Farmers' Cooperative is still remote of being a multi-million cooperative, but the pursuit continues. If the important ingredients for success are frequently nourished by its own members, it will have a promising perspective ahead.

\section{REFERENCES}

Agaton, Sheldon Ives G. 2021. "COVID-19 and Food Security: The Eastern Visayas State University Experience in the Municipality of Burauen." Edited by Darryl Macer. Eubios Journal of Asian and International Bioethics (Eubios Ethics Institute) XXXI (1): 51-54. https://www.eubios.info/EJAIB12021.pdf.

Altman, Morris. 2009. "History and Theory of Cooperatives." International Encyclopedia of Civil Society. https://doi:10.1007/978-0-387-93996-4_102.

Aralar, Reynaldo. 2007. Comments on the Cooperative Code of the Philippines: With Chapters on Electric and Transport Service Cooperatives. Manila: National Book Store.

Araullo, Dennis B. 2006. "Agricultural Cooperatives in the Philippines." 2006 FFTC-NACF International Seminar on Agricultural Cooperatives in Asia: Innovations and Opportunities in the 21st Century. Seoul, South Korea: National Agricultural Cooperative Federation (NACF), Korea, and Food and Fertilizer Technology Center for the Asian and Pacific Region (FFTC/ASPAC). 1-31. https://www.fftc.org.tw/htmlarea file/activities/20110719103351/paper859000900.pd f. 
Castillo, Eulogio T. et. al. 2003. Cooperativism in Agriculture: The Case of Top Four Cooperatives in Region IV, Philippines. Los Baños City: Philippine APEC Study Center Network. https://pascn.pids.gov.ph/files/Discussions\%20Papers/2003/200301.pdf.

Cudis, Christine. 2019. "Cooperative key against poverty, says CDA chair." Philippine News Agency. March 11. https://www.pna.gov.ph/articles/1064237.

Emelianoff, Ivan V. 1995. Economic Theory of Cooperation: Economic Structure of Cooperative Organizations. Washington D.C.: Center for Cooperatives University of California. https://ageconsearch.umn.edu/record/143135/files/EconTheoryCoopBook.pdf.

Fang, Arnold H. 2016. "Linkage between Rural Voters and Politicians: Effects on Rice Policies in the Philippines and Thailand." Asia and the Pacific Policy Studies III (3): 505-517. https://doi.org/10.1002/app5.150.

FG1, interview by Sheldon Ives G. Agaton. 2020. The Cooperative Experience of Cogon Farmers: Food Security for Small Farmers (November).

FG2, interview by Sheldon Ives G. Agaton. 2020. The Cooperative Experience of Cogon Farmers: Food Security for Small Farmers (November).

Foronda, Marcelino, Jr. A. 1993. Introduction to Qualitative Research Methods. Manila: De la Salle University Press.

Inquirer Research. 2019. "In the Know: Janet Lim-Napoles and the Pork Barrel Scam." Inquirer.Net. April 2. https://newsinfo.inquirer.net/1102082/in-the-know-janet-limnapoles-and-the-pork-barrel-scam.

Jacques, Caroline da Graça, Max Richard Verginio, and Dimas de Oliveira Estevam. 2019. "The Connection Between Cooperativism and Decent Work." International Journal for Innovation Education and Research $X$ (7): 678-688. https://doi.org/10.31686/ijier.Vol7.Iss10.1814.

Maboloc, Christopher Ryan B. 2020. "Globalization and Consumer Culture: Social Costs and Political Implications of the COVID-19 Pandemic." Eubios Journal of Asian and International Bioethics XXX (3): 77-79.

Manto-Beltran, Lea. 2017. "Cooperatives as 'catalyst of change'." The Manila Times. March 9. $\quad$ https://www.manilatimes.net/2017/03/09/supplements/cooperatives-catalystchange/316279/.

Mayhofer, Alex. n.d. "Map of Tanauan, Leyte." Nona.Net.

Nierras, Mario C. 2016. "Extension Services' Needs of Small Farmers in Biliran, Philippines." Journal of Advanced Agricultural Technologies III (2): 146-149. http://www.joaat.com/index.php? $\mathrm{m}=$ content\& $\mathrm{c}=\mathrm{index} \& \mathrm{a}=$ show\&catid=42\&id=125.

Nolledo, Jose N. 1996. The Cooperative Laws in the Philippines. Manila: Rex Book Store.

Philiipine Statistics Authority. 2021. GDP posted double digit-growth of 11.8 percent in the second quarter of 2021, the highest since fourth quarter of 1988. 2nd Quarter. Accessed September $2021 . \quad$ https://psa.gov.ph/nationalaccounts/sector $3 /$ Gross $\% 20$ Domestic\%20Product.

2008. Philippine Cooperative Code. Quezon City: Philippine Official Gazette. https://lawphil.net/statutes/repacts/ra2009/ra_9520_2009.html.

Royer, Jeffrey. 2014. "The Neoclassical Theory of Cooperatives: Part I." Journal of Cooperatives XXVIII: 1-19. file:///C:/Users/Justin/Downloads/PARTI FINALVERSION.pdf.

Şahin, Çağatay Edgücan, and Elif Hacısalihoğlu. 2018. "Looking Closer to the New Cooperativism: Practices of Agricultural and Consumer Cooperatives in Turkey." Edited by Çağatay Edgücan Şahin and Arzu Özsoy Özmen. Current Debates in Labor Economics and Industrial Relations (IJOPEC) XXII: 75-88. 
https://www.researchgate.net/publication/324953470_Looking_Closer to the New Cooperativism Practices of Agricultural and Consumer_Cooperatives in Turkey. Tjosvold, Dean. 1984. "Cooperation Theory and Organizations." Human Relations XXXVII (9): 743-767. https://doi:10.1177/001872678403700903.

Wikipedia. n.d. "Leyte."—. n.d. "Tanauan, Leyte."

Zaide, Gregorio. 2003. Jose Rizal: Life, Works, and Writings. Manila: National Book Store.

SHELDON IVES G. AGATON*

Eastern Visayas State University

Tacloban City, Leyte, Philippines

SARAH G. CAJIPO

Eastern Visayas State University

Tacloban City, Leyte, Philippines

DAISY L. LAGDAMEN

Eastern Visayas State University

Tacloban City, Leyte, Philippines

SHERWIN ESPAÑO

Eastern Visayas State University

Tacloban City, Leyte, Philippines

KAY BATHALA SANTOS

Eastern Visayas State University

Tacloban City, Leyte, Philippines

ROSALITA M. DULA

Eastern Visayas State University

Tacloban City, Leyte, Philippines

*Corresponding Author: shelds just@yahoo.com

Received: 13 July 2021 / Accepted: 10 September 2021 / Published: 20 November 2021 